\title{
DERAILMENT OF RELIGIOUS FREEDOM: A STUDY BASED ON THE CONSTITUTIONS OF INDONESIA AND INDIA ${ }^{1}$
}

\author{
Roy Vettikuzhiyil Joseph \\ Philosophy Department \\ Pontifical Athenaeum and Christ University, Bangalore \\ $<$ vettikuzhiyil.joseph@mail.ugm.ac.id>
}

\section{Introduction}

India, being the largest democracy and Indonesia, being the third largest democracy in the world, have significant role in their basic attitude toward religious freedom among the world nations. Based on the Constitutions of the both countries, this study focuses on the religious freedom and its derailment in many ways. Religion plays a vital role in the society in moulding and building the civilization and humanity whether people accept it or not. It can affect the growth of

\footnotetext{
1 I would like to thank Paulus Widjaya and Dicky Sofjan of ICRS for their insightful comments and criticisms on the earlier version of the article. I would also like to acknowledge the generous support of the United Board for Christian Higher Education in Asia (UBCHEA) and Missio, which was given to me all these years.
}

the people positively or negatively. I would like to analyze the background of the Constitutional articles on religious freedom. How do the drafters of the Constitutions conceive of religious freedom in their respective countries? What were their dreams and aspirations when they drafted each article regarding the religious freedom in the Constitution? How much are they implemented or realized?

The gist of the religious freedom in Indian is clearly mentioned in the preamble of the Constitution. The Preamble of Indian Constitution reads as follows:

WE, THE PEOPLE OF INDIA, having solemnly resolved to constitute India into a 1 [SOVEREIGN SOCIALIST SECULAR DEMOCRATIC REPUBLIC] and to secure to all its citizens: JUSTICE, 
social, economic and political; LIBERTY of thought, expression, belief, faith and worship; EQUALITY of status and of opportunity; and to promote among them all FRATERNITY assuring the dignity of the individual and the 2[unity and integrity of the Nation]; IN OUR CONSTITUENT ASSEMBLY this twenty-sixth day of November, 1949, do HEREBY ADOPT, ENACT AND GIVE TO OURSELVES THIS CONSTITUTION. ${ }^{1}$

Subsequently, Articles 25 to 28 elaborate the legal principles of religious freedom in detail. Here, the word "secularism" is of great importance. It is the state ideology. Secularism here means the complete neutrality toward religions. Respect toward all religions, and ultimately guarantees non-discrimination of people by the state on the basis of religious differences. Indian secularism is based on the concept supposedly used first by Mahatma Ghandi of Sarva Dharma Samabhava, which means guarantees equal treatment and respect of all religions. Indian religious ideology is not by any standard an exclusive one. It upholds the principle of social inclusion. India welcomed many religions to its land, and provided conducive atmosphere for their growth. It is the homeland of many religions, although they may not be as popular as Hinduism in India at present. Every citizen of India is provided the right to practice and promote his or her religion peacefully.

1 The Constitution of India, p.1 (original emphasis from author, editor).
Indonesia, being the largest archipelago in the world, one of the most ethnically and culturally heterogeneous nations in the world, plays a vital role today in all spheres of life. More than three hundred ethnic groups coexist with at least two hundred and fifty languages spoken in this vast archipelagic country. Therefore, Indonesia is rich as well as diverse in its culture, tradition and beliefs. It is always a bone of contention to unite all these diverse factors under one umbrella. Prior to the independence of Indonesia, different groups formed nationalist movements, some along religious lines. However, some Westerneducated nationalists like Sukarno stood firmly against the trans-Islamic ideology. They promoted freedom not based on any religious ideology, but took into account the different existing faiths in Indonesia. As a result, the nationalist movement did not identify nationalism with Islamic ideology.

As a result of the relentless efforts by the nationalists, Indonesia realized its independence and was successful in building a consensus on a national Constitution. This is despite hardliners wanting to Islamicize the Constitution, and how they argued fervently for it along the process. However, the great visionaries of Indonesia made a Constitution based on Pancasila (Five Main Principles), and made it the sole foundation of the nation and 
state ideology. ${ }^{2}$ According to Paul Marshall, "The disagreement about religious freedom in Indonesia are usually sharper than most, with reports depicting an increasingly violent and repressive country and other stressing extensive coexistence and harmony." In spite of all these efforts, hidden or sometimes very evident, expressions of radicalization of religion are taking place in both countries.

\section{Islamization in Indonesia}

Islamization is not a process by which its proponents try to convert people from their previous beliefs to Islam, but rather to replace a secularbased government with a government grounded in the doctrines of religion and to bring about a new society wholeheartedly committed to the teachings of Islamic Shari' $a$ in their totality. ${ }^{4}$ They try to make Shari' $a$ as a foundation of the state, and thereby hoping to Islamicize the country. This is possible only by implementing Shari'a, so that the whole spheres of life could be controlled and regulated by Islam. According to Arskal Salim, there are five areas where Shari'a ccould be applied, namely "family issues, financial matters, tazir (discretionary punishments) for committing prohibited

2 Sjafruddin Prawiranegara, Pancasila as the sole foundation, in Indonesia, No.38 (Oct, 1984) p 74

3 Paul Marshall, "The ambiguities of religious freedom in Indonesia". In Review of Faith and International Affairs, Vol.16(1) 2018.

4 Arskal Salim, Challenging the Secular State: The Islamization of Law in Modern Indonesia, University of Hawai'i Press, 2008: p.45. acts, such as liquor consumption and gambling, or for omitting required acts, for instance, the use of headscarf for women, hudud and qisas penalities and Islam both as a basis of the state and as a system governing the country."

The first Indonesian Constitution was drafted between May and August of 1945. The Japanese initiated the drafting process just three months before their surrender to the Allied Forces. ${ }^{6}$ They constituted a committee of 62 members. The main debates in the committee revolved around the role of Islam in the new state. The dispute involved Islamists, who wanted Indonesia Into be an Islamic state and the nationalists who wanted to have an all-inclusive national identity than an exclusive Islamic identity. ${ }^{7}$ Much discussion and debate went on, before they finally bridged their differences by introducing Pancasila. The preamble to the 1945 Constitution of independent Indonesia contains an ideological tenet called Pancasila. ${ }^{8}$ It is composed of five principles, namely; belief in One God, humanity that is just and civilized, unity of Indonesia, democracy guided by the wisdom of representative deliberations and social justice for all Indonesians. ${ }^{9}$

\footnotetext{
5 Ibid, p.46.

6 Hanna Lemer, "Permissive constitutions, democracy, and religious freedom in India, Indonesia, Israel and Turkey". In World Politics, p.17.

7 Ibid.

8 Hyung-Jun Kim, "The Changing Interpretation: Religious freedom in Indonesia". In Journal of Southeast Asian Studies, Vol.29(2) Sep 1998: p.357. 9 Ibid
} 
It is largely viewed as Indonesia's state ideology and principle of social life.

The Islamization is not a new invention but has been in the innermost thoughts of the hardliners. This has become clearer once Indonesia became independent. It is done through the reassertion of an identity, which was for the most part suppressed during the colonial period. ${ }^{10}$ The first of this type of Islamization can be seen in the early 1930's when some Muslim figures like Ahmad Hassan and M. Natsir criticized the lack of Islamic elements within the movement for Indonesia's independence led by the nationalist leaders such as Sukarno.

An attempt to Islamize the social life came about between 1968 and 1998. By Islamizing the social life, the Muslim identity became stronger. When the Islamic leaders realized how difficult and challenging it was to make an Islamic state in Indonesia, they intensified preaching and published great number of Islamic books. The Islamization of society gained its momentum only after the New Order government suspended all discussions regarding the so-called "Jakarta Charter" at the end of 1960's and fused all Islamic parties into a single party in 1973. The Suharto government also imposed Pancasila as the sole ideology of all political parties by the 1980 's. ${ }^{11}$

It promoted an identity among

10 Salim (2008), p.48.

11 lbid, p.49
Islamist groups, and demanded an outer and inner form of Islamization. Their efforts include the formation of Islamic political parties, give Shari'a a constitutional status, promulgating Islamic regulations in some regions and localities, demanding Islamic morality in public life and pushing full recognition of Islamic holidays and events. They also showed strong solidarity with other Muslim nations, and expressed a commitment as devout Muslims who practice Islam in all aspects of human social relations through attempts, for instance, at the introduction of the Islamic penal law and the establishment of the Caliphate.

Hardline Muslims demanded for Islamic nationalism, the nationalists rejected their demand arguing that, "Islam cannot be the basis of the nationalist movement since Christians, Hindus, Buddhists and even animists were involved and would not support a movement intended to favour Islam and place themselves in a subservient position." ${ }^{12}$ Nationalist groups insisted on a religiously neutral state. The logic behind such a claim from Islamic group was based on proportionality of Muslims and their sacrifice for freedom and independence. They also thought that it was unfair to equate almost 90 per cent Muslims to 10 percent of non-Muslims. Thus, it was argued that a higher degree of freedom and upper hand of religious practices for

12 Ibid, p.54 
Islam should be protected by the new government. Though trying their best to implement the Islamic ideology in the new nation-state of Indonesia, they did not succeed completely.

There were many discussions prior to independence regarding the nature of the new independent state. Should Shari'a be implemented in the Constitution? Hatta at this juncture supported a secular law over a Quranic one. Leaders such as Muhammad Yamin, Soepomo and Soekarno, etc., strongly argued for an inclusive Constitution, which included everyone irrespective of their religion. Soepomo explained what a non-Islamic state of Indonesia would look like. Here, one could only appreciate the educational backgrounds of the nationalist leaders, who had strong convictions about Indonesia and the various faiths embraced by the people. Many of them were exposed to Western education and were aware of the secular values of the modern nation-states. It is thus no wonder that they supported a unitary model for Indonesia. Soepomo said:

"If an Islamic state were created in Indonesia then certainly the problem of minorities will arise, the problem of small religious groups of Christians and others. Although an Islamic state will safeguard the interests of other groups as well as possible, the smaller religious groups will certainly be unable to feel involved in the state. Therefore, the ideals of an Islamic state do not agree with the ideas of a unitary state, which we have so passionately looked forward to." ${ }^{\prime 3}$

13 Ibid., p.62.
In order to make a compromise between nationalist leaders and Islamic leaders, nine leaders from different groups had a meeting and came to a compromise. The nationalists group had assurance from Islamic group that the state of Indonesia would not be based on Islam, while the Islamic group received a concession from the nationalist group that the practice of Islamic Shari'a would be obligatory for Muslim citizens. This compromise, later well known as the Jakarta Charter, constitutes the seven words "dengan kewajiban menjalankan syariat Islam bagi pemeluk-pemeluknya" (with the obligation for adherents of Islam to practice Islamic Shari'a) inserted in the formulation of the Pancasila as part of the preamble of the Constitution of 1945. However, on the day after the independence on 18 August 1945, ${ }^{14}$ due to certain political and religious considerations, when Soekarno declared the new Constitution, the seven words were deleted from the Constitution. Though the Islamic group demanded for reserving post of president only for Muslims and Islam as the official religion of Indonesia, the nationalist group won over the hardline stand of Islamic groups. When one analyzes the entire episode through the lens of secularism, the nationalist group clearly won over the hardline Islamic camp.

The Constitution of Indonesia Article 28E clearly envisage speaks

14 Ibid., p.64. 
about the religious freedom in Indonesia. It states, "Every person shall be free to choose and to practice the religion of his/her choice ... Every person shall have the right to the freedom to believe his/her faith, and to express his/her views and thoughts, in accordance with his/her conscience, and every person shall have the right to the freedom to associate, to assemble and to express opinions." ${ }^{15}$ Article 29(2) states that "the state grantees all persons the freedom of worship, each according to his/her own religion or belief." 16

In the following section, I would like to mention some of the ways in which the religious violation of religious freedom in Indonesia takes place. Instances of religious intolerance and violation of religious freedom increased in Indonesia recently although there are efforts to curb it from the broadminded leaders of the country. The Setara Institute, a Jakarta based organization that monitors religious freedom reiterates that an increase in acts of religious intolerance from 236 in 2015 to 270 in 2016 and religious freedom violates rose from 197 to $208 .{ }^{17}$ Indonesian legal system often perpetuates discrimination against religious minorities indirectly. It is mainly through the law, which regulates the house of worship, which requires

15 Art $28 \mathrm{E}$, The 1945 Constitution of the Republic of Indonesia.

16 Art 29 (2), The 1945 Constitution of the Republic of Indonesia.

17 https://hrw.org/news/2017/02/02/indonesiareligious-minorities-under-threat minorities to get official approval from the local community to construct or renovate house of worship. ${ }^{18}$ The law makes difficult for minorities to establish their worship places among the majority. Most of the time it is difficult to get approval from the majority group. So, it has a negative effect on restricting houses of worship and increasing religious segregation. ${ }^{19}$ Marshall (2017) provides a number of examples, which proof the violation of religious freedom. "September 2016, after protests by residents who opposed the Pasar Minggu Protestant Church in south Jakarta, local officials declared that the Church lacked proper permits and must close. ${ }^{20}$

In 2016 April, Muslim hardliners in Bekasi, east of Jakarta, closed the Santa Clara Catholic Church only weeks after it had opened. In spite of having the permits, the local government and police did not prevent the closure. Dispute over the permit can also lead to mob violence. In October 2015, a mob attacked and destroyed 11 Christian Churches in the Aceh Singkil District in the province of Aceh and thousands of Christians fled into the neighboring province of North Sumatra. ${ }^{21}$ The emphasis here is the indirect violation of religious freedom. It violates the religious freedom enshrined in the Constitution of Indonesia Articles 28

\footnotetext{
18 Ibid.

19 See Marshall (2017).

20 Ibid.

$21 \mathrm{lbid}$
} 
and 29 .

Another way in which violation of religious freedom is taking place under the banner of blasphemy law contained in the Article 156 and 156(a) of the criminal code and in the 1965 Presidential Decree (No.1/PNPS/1965) on the prevention of blasphemy and abuse of religion. ${ }^{22}$ Article 156(a) states that "who purposely express their views or commit an act that principally disseminates hatred, misuses or defames a religion recognized in Indonesia, face at maximum five years of imprisonment." Those provisions have been enforced almost exclusively in cases of alleged heresy or blasphemy against Islam and have been increasingly used by radical groups to undercut their opponents and marginalize minorities.

On March 21, 2016, Donald Ignatius Suyanto, a resident of the Hindu majority island of Bali questioned the integrity of Islamic Shahada. He was arrested for blasphemy after having complaint from some Muslims. The most famous incident related to blasphemy law happened recently in the case of former Jakarta Governor Basuki Tjahaja Purnama, known popularly as Ahok. During a public meeting he quoted the Quranic verse of the al-Maidah 51, which warns Muslims against taking Jews or Christians as allies, which was subsequently misinterpreted by

22 Ibid. some Muslim clerics. "The semiofficial Indonesian Council of Ulama (MUI) issued a fatwa accusing Ahok of blasphemy, and the radical FPI, who have attacked Muslim minorities, churches, and nightclubs, called for demonstration demanding that he be tried and imprisoned." 23 On May 9, 2017, he was sentenced to two years in prison by five Judges. There are many examples of this kind can be cited from the history of Indonesia. Minority groups such as Shi'a, Ahamadiyah, Gafatar, etc., have constantly been targeted as victims of discrimination and violence by some groups.

\section{Hindutva Ideology in India}

If Indonesia faces fundamentalism from Islamic groups, in India, the threat is from Hindus. To understand Indian fundamentalism, we need to understand Hindutva and its exclusive mentality and Gandhi's inclusivism and his concept of Sarva Dharma Samabhava (equal treatment toward all religions). Gandhi did not separate religion from politics. ${ }^{24}$ Gandhi brought religious ethics to politics, whereas Savarkar, who was the early proponent of Hindutva ideology, developed it into a form of political militancy. He infused political militancy into religious communities. "In spite of its pretention to be nationalist and

23 Ibid.

24 Rudolf C. Heredia, "Gandhi's Hinduism and Savakar's Hindutva". In Economic and Political Weekly, Vol.44(29) July 18-24, 2009: p.62. 
modern, its militant chauvinism and authoritarian fundamentalism make Savarkar's Hindutva the antithesis of Gandhi's Hinduism." ${ }^{25}$ The word Hindutva gained more circulation after it appeared as a title of a book written by V.D. Savarkar, published in 1923. Savarkar and Gandhi are the two proponents of two distinctive forms of Hinduism. ${ }^{26}$ Once S. Radakrishnan asked Gandhi, what is your religion? For that Gandhi replied, "My religion is Hinduism which, for me, is religion of humanity and includes the best all the religions known to me. I am being led to my religion through Truth and non-violence, i.e. love in the broadest sense." 27

In his book Savarkar defines Hindus as one who regards the entire subcontinent as his motherland/ fatherland, is descended of Hindu parents and considers this land holy. Thus three essential elements of Hindutva are a common nation, a common race and a common civilization. ${ }^{28}$ Savarkar's Hindutva includes only Indian religions whereas the Indian nationalists include all the religions practiced in India. Gandhi's concept of religion is far superior than Savarkar's. Gandhi stressed on the reality of God, the unity of all life and

25 Ibid

26 Arvind Sharma, "On Hindu, Hindustan, Hinduism and Hindutva". In Numen, Vol.49(1) 2002: p.21.

27 S. Radakrishnan, ed; Contemporary Indian Philosophy, p.21.

28 Arvind Sharma, "On Hindu, Hindustan, Hinduism and Hindutva" In Numen, Vol.49(1) 2002: p.22. value of ahimsa. He redefined Hinduism as a path of service. For Gandhi, God is truth and says that truth is God. He also upholds the idea of non-violence in his religious understanding. Gandhi says, 'Ahimsa is my God and truth is my God. When I look for Ahimsa, truth says, "Find it through me." When I look for truth. Ahimsa says, "Find it through me." ${ }^{29}$

Gandhi did not separate religion from politics. He stressed the religious ethics to politics rather than political militancy into religious communities. ${ }^{30}$ Whereas Hindutva defines India as Hindu and try to include all religions to be Hindus. It is a very narrow and exclusive definition of Hinduism. Gandhi was always aware of the fact of the existence of multiple dimensions of truth. He could understand various faces of truth. He had strong faith in the concept of Sarvadharma samabhava.

The banner of Hindu nationalism is carried by three organizations, namely RSS- Rashtriya Svayamsevak Sangh, Vishwa Hindu Parishad (VHP) and Bharatiya Janata Party (BJP). These are the ideological offspring of Hindu Mahasabha founded in 1915 in reaction to the formation of the Muslim League. They proclaim the superiority of the Hindu race and culture. ${ }^{31}$

29 Mohandas Gandhi, "Collected Works". In Young India, June 4, 1925: p.89

30 Rudolf C. Heredia, "Gandhi's Hinduism and Savakar's Hindutva" In Economic and Political Weekly, Vol. 44(29) July 18-24, 2009: p.63.

31 R. Scott Appleby, The Ambivalence of the Sacred, p.110. 
The Hindu nationalist movements combine fundamentalist style religious reactionism to secularism and pluralism with an ethno nationalist's ideology. ${ }^{32}$

The Hindu groups reconstruct religion around nationalist themes in order to challenge the secular order in India. The main concept of Hindutva define geographic, racial and religious boundaries of Hinduism and India alike it. It rejects the pluralist secular state and would replace it with a Hinduized state occupying the land within sacred boundaries. ${ }^{33}$ Its culmination could be seen in the destruction of Babri Masjith. The VHP-BJP-RSS claimed that the site of the mosque in Ayodya in the state of Utter Pradesh in India is the exact spot of the birthplace of the Lord Rama. They claimed the existence of a temple on the spot in the name of Rama. However, when Babur came to India, founding the Mughal dynasty demolished the Hindu temple, and built a mosque, known as Babri Masjith, in $1528 .{ }^{34}$ This seems very difficult to proof historically.

By 1985 onward, nationalist Hindus started playing religious card. They demanded for regular worship and replacement of Mosque. In 1990, then president of BJP made a Rathayatra (Pilgrimage on Chariot) to Ayodya from Gujarat. Though he could not reach Ayodya, it gave them a strong

32 Ibid.

$33 \mathrm{lbid}$, p.112.

34 Ibid political mileage. On December 6, 1992, over 200,000 Hindu fanatics arrived at Ayodya and less than five hours tore down the Babri Mosque. ${ }^{35}$ It was a great blow on the face of Indian secularism. The aftermath of this historical blunder was tremendous. Thousands of people were killed in both sides. Many riots and communal violence were broken out in various parts of the country. The wounds resulted from this historical intolerant act is not yet cured.

The fanatic Hindus could win politically had they consolidated the majority Hindus by fabricating false stories and injecting religious poison among the simple-minded. They made use of religious sentiments for political gains. As per Hindu extremist discourse, the Muslim could remain in the nation only by accepting the hegemony of Hinduism. BJP managed to get only two Lok Sabha seats in 1984 general election. But by 2014 election, they could secure 282 seats in the 543 seats Lok Sabha. They also formed the central government under Narendra Modi, which paved the way for the consolidation of Hindu votes. The majority Hindus felt that they were at risk, and that only a party like BJP could protect their interests.

Religious freedom in India is detailed in the Constitution from Articles 25 to 28 . The title of the section itself is "right to freedom of religion".

35 Ibid, p.113. 
Articles 25 to 28 are as follows:

25(1): "Subject to public order, morality and health and to the other provisions of this part, all persons are equally entitled to freedom of conscience and the right freely to profess, practice and propagate religion."

26: "Subject to public order, morality and health, every religious denomination or any section thereof shall have the right to establish and charitable purposes, to manage its own affairs in matters of religion, to own and acquire movable and immovable property and to administer such property in accordance with law."

27: "No person shall be compelled to pay any taxes, the proceeds of which are specifically appropriated in payment of expenses for the promotion or maintenance of any particular religion or religious denomination."

28: "No religious instruction shall be provided in any educational institution wholly maintained out of state funds." 36

It may be noted that the provisions of the Indian Constitution regarding right to religious liberty cover all the freedom relating to religion set forth in the Universal Declaration of Human Rights, which was adopted by the General Assembly of the UN on December 10, 1948. Article 18 of the document states:

"Everyone has the right to freedom of thought, conscience and religion; this right includes freedom to change his religion or belief, and freedom; either alone or in community with others and in public or private, to manifest his religion or belief in teaching, practice, worship and observance." ${ }^{37}$

Therefore one can very well say that Indian Constitution protects the

36 The Constitution of India, p. 13-14

37 www.claiminghumanrights.org/udhr-article-18html interest of every citizen. It provides all opportunities to practice his or her religion as per the conscience in conformity with public order and health. But today there are many cases of breach of law could be seen in India. Due to the uprising fundamentalists groups into power, such incidents are legitimized or sometimes seem to be sponsored indirectly by the government. Here, I would like to show the breach of law against religious freedom citing two incidents, one against Christians and another against Muslims.

A religious violence took place on August 25-28, 2008 in the Kandhamal district of Odisha state. It was a real breach of law of religious freedom. A Hindu mob had set fire to many Christian settlements causing at least 45 people killed. The reason they put for the communal violence was the murder of Swami Lakshmananda, who believed to have pledged to eliminate Christianity from the country. He was killed along with three fellow leaders of the VHP and a boy in the girls' religious school at his Jalespata ashram in Kandhamal district on August 23. Hindu hardliners accused Christians the murder of Swami although it was proven that Maoist had committed the murder, as the former also spoke against the latter. However, Hindu fundamentalists did not accept the murder, and started to persecute and attack Christians.

More than 18,000 people were 
injured and 50,000 internally displaced. Some tribal even fled away to broader districts in neighboring states. Some 310 villages were affected with 4640 homes, 252 churches and 13 educational institutions torched during the attacks. ${ }^{38}$ Then Prime Minister of India condemned it as the act of shame.

On June 29, 2010, a fast track court was set up after the Kandhamal riots found Manoj Pradhan, a Member of BJP and member of the legislative assembly of Odisha, was found guilty of murder of Parikhita Digal, a Christian from Budedi village, who was killed by the mob on August 27, 2008. He was sentenced to seven years of rigorous punishment. A number of others were also punished by the court for rioting. ${ }^{39}$

Recently a Muslim man named Mohammad Akhlaq of 52 years was killed by a mob, who accused him of eating beef in Northern India, in place called Bisada, Dadri. ${ }^{40}$ On September 28, 2015 evening, one of Akhlaq's neighbors accused him of stealing and slaughtering his missing calf. The mob rushed into the house of Akhlaq and started beating Akhlaq and his son. Akhlaq was killed, while his son was seriously injured. They seized meat from Akhlaq's house. But only mutton was found after forensic testing. ${ }^{41}$ The

38 https://en.wikipedia.org/wiki/religious-voilence-inodisha

39 Ibid.

40 https://www.theattantic.com/international/ archieve/2015/10/india

41 http://en.wikipedia.org/wiki/2015-dadri-moblynching court found 20 culprits, and sent them to jail. The family of Akhlaq fled to Delhi, a painful departure from his ancestral land.

It is very clear from the abovementioned riots and violence that violation of religious freedom takes place quite often in India. It seems to have multiplied when the Hindutva parties came to power. When these riots occurred, police and local administration seemed to have turned a blind eye, and gave the fanatics quiet support. Today, such religious rioting and violation take place every now and then across the country, and threaten religious freedom, which is guaranteed in the Constitution. Now, the majority decides what to eat and when to eat. They are even ready to kill a person or chase the family out of the village in the name of food habits. Thus, they connect everything with religion. No doubt, it is the political parties that are behind such unethical and inhumane development.

\section{Conclusion}

It is true that both countries, India and Indonesia, have successfully celebrated more seventy years of independence. It is an undeniable fact that both countries have contributed a lot to the world at large, and made significant steps in the areas of human rights and democracy. At the same time, the radicalization of religion in India and Indonesia seem to have been perpetuated by fundamentalists or 
conservatives, whether it be in the name of Islam in Indonesia or Hinduism in India. Therefore, the Islamization of Indonesia and Hindutvization (making India as Hindu) of India are the hidden agenda of the extreme conservative groups in both countries. Historical evidences show that this process of radicalization is not new, but it has existed in the imagination and minds of the conservatives from the very outset.

All the cases presented in this article show that they violate religious freedom. In all these instances, the perpetuators were the majority, while the victims were the minority. To safeguard the interests and beliefs of the minorities, the only solution is to maintain the law in its pure spirit without dilution. Nevertheless, the above analysis on the violation of religious freedom would serve as a good warning for us to be vigilant.

Many similarities can be seen between Indian secularism and Indonesia's Pancasila, Hindutva of India and Islamization of Indonesia. According to Sofjan (2016) the minoritization and criminalization of Shia Muslims in Indonesia affect the credibility of the longheld tradition of Islamic tolerance of Indonesian Muslims throughout generations. ${ }^{42}$ The view was supported by Human Rights Watch staff in Indonesia. On September 21, 2017, addressing 72nd UN General

42 Dicky Sofjan, Minoritization and criminalization of Shia Islam in Indonesia, P.44
Assembly, the Vice President of Indonesia Jusuf Kalla claimed that religious tolerance in Indonesia as "better than in other countries", and could even pose as a "model" for other countries. The UN Human Rights Watch staff in Indonesia described his claims as "fantasy". 43

The recent Pew Research Center study of 198 countries ranked India as fourth worst in the world for religious intolerance. ${ }^{44}$ During the 2008 Kandhamal religious riots, the Vatican expressed its concern by stating "its solidarity with local churches and the religious orders involved, and condemns those actions, which are an affront to dignity, people's freedom and endanger peaceful civil coexistence". ${ }^{45}$ These cases of religious freedom violations indicate that both countries have a lot in terms of achieving the dreams of its founding fathers. Therefore, both countries are not exactly good exemplary models of the world on religious tolerance. Both Indonesia and India need to meet the expectations of the world to ensure that religious freedom is guaranteed and that minority groups are protected.

Although during these episodes of religious violence, the political leaders had publicly urged the people involved to stop their violence, in

43 Paul Marshal, The Ambiguities of Religious Freedom in Indonesia, Published Online

44 https://qz.com/india-is-the-fourth-worst-countryin-the-world-for-religious-violence

45 www.stuff.co.nz/world/six-killed-in-india-religiousriots-vatican-condomns 
reality it did not happen. Somehow they are supporting the religious violence in such a way that would help them polarize the votes of the people toward a desired sector for their political gains. Only by a genuine approach toward the fundamental provisions given in the Constitution can such extremist movements be overcome, with sincere effort from the part of the country's politicians and leaders. The lost glory of both countries can be regained only by faithfully adhering to their own Constitutions. Since both countries are known for their diversity and plurality, it is not easy to keep everyone under one umbrella if not bound by a common destiny. In this matter, the role of state is the impartial implementer of the law and simultaneously guardian of religions, whereby religious leaders have the responsibility to guide not only their followers, political parties should be aware of the reality of pluralism in these countries and develop mutual respect for one another. It is my view that both Pancasila in Indonesia and secularism in India could surely ensure the peaceful coexistence of different faiths under one umbrella, while attaining the wisdom of their founding fathers.[]

\section{References}

Arskal Salim, Challenging the Secular State: The Islamization of law in modern Indonesia, University of Hawai Press, Honolulu, 2008.

Hanna Lemer, Permissive constitutions, democracy, and religious freedom in India, Indonesia, Israel and Turkey, World Politics.

Hyung-Jun Kim, The changing interpretation: religious freedom in Indonesia, in Journal of Southeast Asian studies, Vol.29(2) September 1998: 357-373, Published by Cambridge University Press on behalf of Department of history, National University of Singapore.

Rudolf C. Heredia, “Gandhi's Hinduism and Savakar's Hindutva”. In Economic and Political Weekly, Vol. 44(29) July 18-24, 2009: p.62-67.

Arvind Sharma, “On Hindu, Hindustan, Hinduism and Hindutva”. In Numen, Vol.49(1), Brill, 2002: p.1-36.

S. Radakrishnan,ed; Contemporary Indian Philosophy, George Allen and Unwin Ltd, London, 1936.

Mohandas Gandhi, Collected works, (Young India, 4 June 1925), 100 Vols, Government of India, New Delhi.

R. Scott Appleby, The ambivalence of the sacred, Rowman and Littlefield Publishers, Inc. Oxford, 2000.

The 1945 Constitution of the republic of Indonesia. As amended by the first amendment of 1999, the second amendment of 2000, the third amendment of 2001 and the fourth amendment of 2002.

The Constitution of India, published by Government of India Ministry of law and justice, New Delhi, 2015.

Paul Marshall, “The ambiguities of religious freedom in Indonesia”. In Review of Faith and 
International Affairs, Vol.16(1) 2018

Sjafruddin Prawiranegara, "Pancasila as the Sole Foundation". In Indonesia, No.38 Southeast Asia Program Publications at Cornell University, October 1984: p.74-83.

Sofjan, Dicky, "Minoritization and criminalization of Shia Islam in Indonesia". In Journal of Southeast Asian and Middle Eastern Studies, Vol. 39(2) Winter 2016: p.29-45.

\section{Websites}

www.claiminghumanrights.org/udhr-article-18html

https://en.wikipedia.org/wiki/religious-voilence-in-odisha

https://www.theattantic.com/international/archieve/2015/10/india

http://en.wikipedia.org/wiki/2015-dadri-mob-lynching

https:/hrw.org/news/2017/02/02/indonesia-religious-minorities-under-threat

https://qz.com/india-is-the-fourth-worst-country-in-the-world-for-religious-violence

www.stuff.co.nz/world/six-killed-in-india-religious-riots-vatican-condomns 